\title{
Experience of Field Geomorphological Research Study on the Territory of the Volzhsko-Kamsky Natural Reserve
}

\author{
Gasanov I.M. \\ Kazan Federal University, Institute of Management, Economics and Finance, Kazan, 420008, Russia
}

Kurbanova S.G.

Kazan Federal University, Institute of Management, Economics and Finance, Kazan, 420008, Russia

Pratchenko O.V.

Kazan Federal University, Institute of Language, 420008, Kazan, Russia

\section{Doi:10.5901/mjss.2014.v5n24p448}

\section{Abstract}

Since the 1940s on the territory of the Raifsky site of Bolshoy Volzhsko-Kamsky biospherical reserve (BVKBR) "UNESCO" the geomorphological conditions are subject to very detailed study. The study of modern geomorphological phenomena and processes on the territory of the Raifsky reserve was the main purpose of the work and geomorphological studies. Formation of the relief the territory under study is closely connected with the history of development of the valley of the Volga River. The territory of the reserve is very heterogeneous by morphology, genesis and history of the development of land forms. It is important to identify the interaction of the relief with the processes of territory development and settlement, i.e. geomorphological conditions are the pledge of successful development of the region.

Keywords: geomorphologic research studies, relief, creep, erosion-accumulative processes, gully erosion, reserve.

\section{Introduction}

Relief is the main element of the landscape. Many exogenous factors act influence the environment through the relief, which gives it special significance as the characteristic of the human living environment, as far as in the same climatic and structural-tectonic conditions the natural and antropogenous components of ecosystems develop differently, but in close cooperation with each another as well [1-7].

The Raifsky site of the Volzhsko-Kamsky natural reserve is situated on the left slope of the Volga valley, on its high Quarternary terraces above the floodplain. The terraced terrain is separated by valleys of the small $(37 \mathrm{~km})$ left tributary of the Volga river. The river Sumka and its tributaries, numerous ravines, gullies and ravines. The surface of terraces is complicated by karst and karst-suffusion cavities and craters, many of which are occupied by lakes. Quarternary alluvial deposits of the Volga river are underlain by sandy-clayey alluvial-lacustrine sediments of the Pliocene, among which the limestone and dolomite rocks of the Kazan layer of the upper sheds of the Permian system are locally preserved. Pliocene strata ranging from 0 to 140 meters performs deep (up to $100 \mathrm{~m}$ ) valley cuttings in the Permian rocks. The lower part of the strata is composed of sand and pebble alluvium, upper - of sandy-clayey lacustrine sediments. As well as throughout the Volga region, the time of formation of these deep paleo-valleys and their deposits belongs to the Pliocene.

Paleo-relief of the Raifsky reserve area (north-western, northern and north-eastern parts) are on the southern slopes of Volga paleo-valley of Volga with absolute altitudes minus $20-80$ meters. The southern part is located on of the limestone-dolomite paleo- watershed divide with absolute altitudes of the buried erosion surface from 0 to 65 meters. In the valley of the river Sumka near the village llinskoe the terrains of the Kazan stage crop out. The amplitude of the altitudes of the buried relief of the Permian terrains of all area of the Raifsky reserve is $145 \mathrm{~m}$ (from - 80 to +65 ). The course with altitudes from 0 to $-20 \mathrm{~m}$ forms the transition from the paleo watershed divide to the paleo-valley.

Permian and Pliocene deposits in this region are covered with Quaternary sediments everywhere; they form three clearly defined alluvial above flood-plain terraces of the river Volga. The upper terrace of the river Volga - the highest and the oldest - occupies the north-east part of Raifsky reserve. The protogenous initial surface of the terrace had absolute 
altitudes less than 135 - 140 meters. The smooth slope of the terrace is separated by the valley of the river Sumka and the upper flow of its small $(12 \mathrm{~km})$ tributary of the river Sopa. The slopes of both valleys are scoured by cloughs and ravines.

At the bottom of the terrace the alluvium, that composes it, is represented by channel sand-gravel-pebble deposits which are opened up in the outcrops of the right bank of the river Sumka in $3 \mathrm{~km}$ to the North-East from the village Belobezvodnoe and up the river near the village Ivanovsky. Upslope the sands are inter-lain with siltstones, clay loam and clays representing floodplain facies. Total output of alluvial suites is up to 40 meters, its sole lies at absolute altitudes of 70 - 75 meters ( $30-35$ meters above the low water level of the old Volga river).

Within 6 - $7 \mathrm{~km}$ to the North from the Lake Belobezvodnoe, near the north-eastern border of the Raifsky area the alluvium of the upper terrace leans against the terrains of the Upper Perm that compose the left valley slope of the valley of the Volga river and the surrounding it denudation plain of 170 - 200 meters height. Within 2 - $3 \mathrm{~km}$ to the North from the Lake Belobezvodnoe the alluvium of the lower middle terrace of Volga is joined to the alluvium of the upper terrace and older sediments of the Pliocene and the Eo-pleistocene that underlies it. Thus, the width of the upper terrace of the site is just 4 - $5 \mathrm{~km}$.

The middle terrace stretches by the wide $(10-12 \mathrm{~km})$ strip from the West - North-West to the East - South-East. It has a wavy surface separated by the valleys of the river Sumka and its drying-up left tributary Ser-Bulak, by smoothslope, often bogged up hollows. Cloughs and small valleys with drying-up streams are expressed in the relief more sharply. On the watershed divides between the valleys, ravines and cloughs the absolute altitude marks range within 100 - $120 \mathrm{~m}$. They are close to the level of the primary accumulative surface of the terrace which probably does not exceed 120 - 125 meters. On the North-West the middle terrace is connected with the smooth upper slope, and it is possible to judge about the change of terrace levels only by the change of prevailing heights and geological structure. In the South, the middle terrace is separated from the lower one by the well-defined terrace with up to 40 - 45 meters height.

The river Sumka $(36 \mathrm{~km})$ is an important relief-forming element of the entire Raifsky reserve. River Valley is characterized by good development and abrupt asymmetry of the slopes: the left slope is flat, and the undergoing to the underwashing right slope is steep and high everywhere. The absolute height of the terrace is $85 \mathrm{~m}(32 \mathrm{~m}$ above the reservoir level). The height of the rim is 72 meters. The slope of the terrace is not forest, it is formed by diluvial clay loam and separated by numerous small gullies that accelerate erosion and gravity processes.

\section{Methodology}

Relief, its forms, parts of forms and microforms are the main object of the geomorphological study. The study of topography and exogenous processes is to describe their appearance (morphology) with field mapping, to establish their size and position in space (morphometric), to determine of their origin (genesis) and to identify the stage of development, the sequence and time of their formation (age).

Field studies are carried out on the territory of the Raifsky site of the Big Volzhsko-Kamsky Biosphere Reserve " UNESCO" since 2006 and are regulated by the existing methodological instructions, instructions on organization and performance of geomorphological and geological surveying works [7].

The following stationary and semi-stationary observations were carried out during the field geomorphological studies: the study of intensity of gully erosion processes in the buffer zone of the reserve; the study of the speed of accumulation of sand deposits on the alluvial fans of the river Sumka; the study of slope processes and creep; construction of cross sections on the site between the lakes Raifskoe and llinskoe along the line of pits' extension; the study of sandy sediments of terraces of Sumka and Volga; the study of the abrasion processes - underwater of river banks of Sumka; geomorphological map drawing.

Research work concerning accumulative, erosion-accumulative and slope processes, the study of abrasion processes was carried out on the ground. 3 sites were organized for precise alignment of all constituent elements of comprehensive observation and geomorphological survey on the territory of the Raifsky BVKBR. There the periodical monitoring for the topography and the mass of the moved material under the action of relief-forming processes was carried out since 2006.

Measurement technique to study the current dynamics and the specific methodology for the organization of sites varies depending on characteristics of the study of relief-forming processes and the areal coverage of researches, when the point (creep) and profile (holding of theodolite field traverse of alluvial fans, the underwater of the banks of the river Sumka) observations were applied. Standard instruments (theodolite, GPS - receiver, elevation meter) and leveling mark were used for the organization of sites.

The study of the alluvial fans was carried out on the areas of the river fall of Sumka into the karst lakes - Raifskoe, 
Bezobezvodnoe and llinskoe. Description and laying of the theodolite field traverse, bathymetric profiles of "the Raif" lakes and building of cross sections on sites between lakes was carried out. High-altitude position of the network of intermediate points to draw detailed images of the cones on the plan using the contour was defined on the alluvial fans.

Observation of the underwater of the banks of the river Sumka was on the site of one of the largest bends of the river. Another type of work carried out within the frames of the field research, is to find the most abrasion-unstable (washed out) banks of the river Sumka and to fix them using preliminarily numbered leveling marks. The leveling marks were pitched into the ground on a small $(0.5-1 \mathrm{~m})$ distance from the edge of the washed out shore. 8 regular and 1onetime stations with leveling marks were organized.

The study of the creep processes is an important scientific research problem to be solved in the study of the terrain. In organizing these point stations the authors used a very simple - from the technical point of view - methodology of A.P. Dedkov, V.A. Duglav and V.I. Mozzherin [8, 9]. A total of 10 exploring pits were dug, with 1,4-1,8 metres deep. According to the plan, these exploring pits are located on 3 lines. The first line is on the left bank of Sumka, on gentle forest slopes of the North-Western exposure; the second one - on the right convex-concave slope of the South-Eastern and Eastern exposure, and the third one - on the gentle treeless (meadow) slopes of the right bank of Sumka. The distance between the exploring pits on the lines is 250 - 320 meters in average.

In the process of foundation of the exploring creep pit in its aseismic wall that is oriented along the slope digging, metal plates of $3 \times 3 \mathrm{~cm}$ in size are forced along the plumb line in $5 \mathrm{~cm}$. The position of the vertical plumb line is recorded before the backfilling of the exploring pit by the iron rod (dowel) $50 \mathrm{~cm}$ long, driven into the bottom of the pit and on the surface on the front wall of the pit with a space of $10 \mathrm{~cm}$.

\section{Results}

In the study of the territory of the Raifsky area of the BVKBR by change of the prevailing heights and the geological structure we identified six areas with surfaces and landforms confined to them. Most part of the territory (58.1\%) is occupied by the alluvial middle neo- Pleistocene surface of the fourth above-floodplain terrace of the river Volga. It stretches from the West-North-West to the East-South-East and has the wavy surface divided into parts by the valley of Sumka and Ser-Bulak. The absolute level marks of the territory are from $67,4 \mathrm{~m}$ (the level of the lake Linëva) to $110,4 \mathrm{~m}$ (on the North-Western border of the reserve area). On the watersheds between the valleys, cloughs and ravines the relative heights reach 120 meters. The karst, erosion, suffusion and creep-landslide processes are developed on the surface. In some places the surface is complicated by the dunes. In the North and North-West the surface of the fourth above-floodplain terrace is connected with the alluvial Eo-Pleistocene surface of the sixth rock-defended above-floodplain terrace of the river Volga (with the square of 32 square kilometers of the area - 17.2\%). The absolute marks of the territory are 76,4 (the water edge in the middle flow of the river Sumka) - 112,9 (in the North-East of the reserve) meters. The eroded surface is at the height of $125-130$ meters. The surface is erosion-accumulative, the alluvium that composes it lies to the lacustrine sediments of the lower Eo-Pleistocene. The width of the surface on the site under consideration is only $3-5 \mathrm{~km}$. In the places of developments of the carbonate rocks the karst and karst-suffusion cavities and funnels are found.

The delluvial-solifluction Late-Neo-Pleistocene-Holocene surface of steep (less than 10 degrees) lower parts of slopes is developed in the North, outside the Raifsky reserve. It occupies approximately 21 square kilometers (11.3\%) of the shooting territory. The absolute height marks range from 86,6 $\mathrm{m}$ (the level of the lake Chernoe) to 126,9 (in the East near the village Krasny Caral) and $140 \mathrm{~m}$ (in the West - near the village Bolotnye Kluchi). There is the development of karst-suffusion holes, gully erosion, landslides.

The alluvial Late-Neo-Pleistocene-Holocene undifferentiated surface of the floodplain, of the first and second above-floodplain terraces of the river Sumka $\left(9 \mathrm{~km}^{2}-4,8 \%\right.$ of the total area) is located within the valley of the river Sumka. The surface is significantly different on the geological structure from the coast host arrays and coastal separating watershed spaces, and it is composed of modern alluvial deposits, mainly water-saturated. The absolute level marks of the territory are 64,4 - 84,6 meters (the water's edge of the river Sumka in the middle and upper flow).

Denudation surfaces of watersheds - the erosion and solifluction Late-Neo-Pleistocene of steep (more than $10^{\circ}$ ) upper slopes (10 km $\left.{ }^{2}-5,4 \%\right)$ and the denudation Late-Eo-Pleistocene - Early-Neo-Pleistocene of the middle plateau (6 $\mathrm{km}^{2}-3,2 \%$ ) are the most Northern regions covered by geomorphological shooting. Here asolute marks reach 180-240 meters. Here the river Sumka heads; erosion (gullies and ravines network with steep erosion-denudation slopes), landslide, karst-suffusion and subsiding processes are developed.

In total, in the study of alluvial cones 127 points and 5 observing stations with registration benchmarks were laid. The parts of the coastline of the river, lakes, the borders of bends of the alluvial cones of rivers were observed and 
recorded and sketched out by theodolite traverse. It was found that the greatest increase of the height of the alluvial cone was on the lake Belobezvodnoe: 0.5 meters. Together with the research study of the alluvial cones the study of sand deposits of the terraces of Sumka and Volga was carried out: the grain size analysis of sands by sample testing (15-20 samples) and the particle screen analysis of sand deposits with the calculation of volume of fractions of different sizes.

In total 20 rack points with the first theodolite station were established in the study of the caving of the banks of Sumka. Shooting and measurements showed that the abrasion and displacement of the shoreline is at an average speed of $30-40 \mathrm{~cm} /$ year.

The study of the creep processes is an important research problem solved in the field environment [10-12]. In total 10 pits (Table. 1) with the depth of 1.4 - 1.8 meters were dug.

Table 1. Data on slope of creep pits

\begin{tabular}{|c|c|c|c|c|c|}
\hline Number of creep pit & $\begin{array}{c}\text { Depth of pit, } \\
\text { sm }\end{array}$ & Number of plates & $\begin{array}{c}\text { Grid coordinates } \\
(x, y)\end{array}$ & Altitude, $\mathrm{m}$ & Distance between pits, $\mathrm{m}$ \\
\hline \multicolumn{6}{|c|}{$1^{\text {st }}$ sector (forest, the left bank of the river Sumka) in azimuth $335^{\circ}$} \\
\hline \multirow{2}{*}{1} & \multirow{2}{*}{149} & \multirow{2}{*}{28} & 9356272 & \multirow{2}{*}{83} & \multirow{6}{*}{$\begin{array}{l}280 \\
450\end{array}$} \\
\hline & & & 6195892 & & \\
\hline \multirow[b]{2}{*}{2} & \multirow{2}{*}{172} & \multirow{2}{*}{31} & 9356248 & \multirow{2}{*}{85} & \\
\hline & & & 6196036 & & \\
\hline \multirow{2}{*}{3} & \multirow{2}{*}{134} & \multirow{2}{*}{25} & 9355931 & \multirow{2}{*}{81} & \\
\hline & & & 6196285 & & \\
\hline \multicolumn{6}{|c|}{$2^{\text {nd }}$ sector (лес, the right bank of the river Sumka ) in azimuth $360^{\circ}$} \\
\hline \multirow{2}{*}{4} & \multirow{2}{*}{177} & \multirow{2}{*}{34} & 9355485 & \multirow{2}{*}{91} & \multirow{8}{*}{$\begin{array}{l}400 \\
300 \\
250\end{array}$} \\
\hline & & & 6197631 & & \\
\hline \multirow{2}{*}{5} & \multirow{2}{*}{173} & \multirow{2}{*}{28} & 9355391 & \multirow{2}{*}{100} & \\
\hline & & & 6197070 & & \\
\hline \multirow{2}{*}{6} & \multirow{2}{*}{175} & \multirow{2}{*}{33} & 9355552 & \multirow{2}{*}{95} & \\
\hline & & & 6198410 & & \\
\hline \multirow{2}{*}{7} & \multirow{2}{*}{162} & \multirow{2}{*}{31} & 9355579 & \multirow{2}{*}{97} & \\
\hline & & & 6198653 & & \\
\hline \multicolumn{6}{|c|}{$3^{\text {rd }}$ sector (meadow, outside the village Belobezvodnoe) in azimuth $296^{\circ}$} \\
\hline \multirow{2}{*}{8} & 140 & 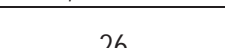 & 6198653 & 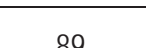 & \\
\hline & 140 & $\angle 6$ & 6201554 & 89 & \\
\hline 0 & 158 & 30 & 9362013 & & 320 \\
\hline$y$ & 158 & 30 & 6201744 & 89 & 320 \\
\hline 10 & 157 & 30 & 9361764 & 91 & \\
\hline 10 & 157 & 30 & 6201896 & 91 & \\
\hline
\end{tabular}

According to plan, these pits are located on 3 lines: the first is on the left bank of the river Sumka, on gentle slopes of the north-western exposure; the second one - on the right convex-concave slope of the South-Eastern and Eastern exposure, and the third one - on the flat treeless (meadow) slopes of the right bank of Sumka.

In total 296 metal plates (25 - 34 plates per pit) were laid for further identification of mechanisms and dynamics of development of creep processes. On the basis of the data of the excavated pits after 2 years we can conclude that the displacement of soil in forested and grassland areas is observed up to the depth of $120 \mathrm{~cm}$. Maximum creep rate is on the meadow areas (30-36 mm a year), and in the forested areas $-5-13 \mathrm{~mm}$ (on the left bank of the river Sumka the creep rate was 0,5 - $1 \mathrm{~cm}$, on the right bank - 10-13 $\mathrm{mm}$ a year).

Modern soil and gully erosion affects only treeless arable lands which are particularly susceptible to human impact. These places are located in the northern part of the reserve. Erosion products are accumulated on the floodplain bench complex of small rivers [13], a large mass of sediment flows into the river Sumka and into the lakes in its valley, causing its siltation and general degradation of the drainage system [14].

\section{Statements}

Modern relief of the Raifsky reserve owes its origin to the complex natural and anthropogenic activities.

During the geomorphological studies on the territory of the Bolshoy Volga-Kama Raifsky reserve the development 
of modern exogenous processes, including gullying, slow displacement of soil (creep), caving of the riverbanks was studied.

Geological and geomorphological profiles across the strike of the main elements of the relief were set up, 10 creep pits were laid on the treeless and wooden lots of the Valley of the river Sumka, the data on the key reference sections of Quaternary deposits was obtained. In order to conduct the graphic recording of the river during the flood phase of the water regime the mapping of two alluvial cones of the river Sumka was carried out in the places of its fall into the lakes Raifskoe and Beloe. In the study of abrasion-unstable (undermined) banks and dynamics of meandering of the river Sumka it was found that the abrasion activity of the river Sumka is significant and considerably varies from year to year (0,5-0,7 meters a year). The processes upstream the river Sumka from the lake Beloe on sharp turns of the river Sumka are particularly intense in spring.

According to field observations and surveying work, cartographic, textual materials, as well as large-scale satellite images the geomorphological map of the scale 1: 50000 was mounted. The way of color plastics (qualitative background), i.e. the coloring by different colors and shades depending on the age of the relief surfaces, as well as the ways of areas, localized icons and linear signs, was widely used on the map.

\section{Conclusion}

The research work of the study of the relief on the territory of the Raifsky Reserve was carried out in accordance with the methodology which is the most optimal in terms of quality, time spent and technical capabilities.

Further studies are of great interest for identification of the mechanism of formation of relief-forming processes, for forecasting and identification of dynamics of modern exogenous and creep processes.

\section{References}

Dedkov, A.P., V.I.Mozzherin, A.N. Sharifullin and R.R. Denmukhametov, 2005. Recent denudation of the Earth's plains according to data on sediment and dissolved substance load. Izvestiya Akademii Nauk, Seriya Geograficheskaya, 5, pp. 30-38.

Knox, J.C., 2006. Floodplain sedimentation in the Upper Mississippi Valley: Natural versus human accelerated. Geomorphology, 79 $(3,4)$, pp. 286-310.

Klimek, K., 2002. Human-induced overbank sedimentation in the foreland of the Eastern Sudety Mountains. Earth surface processes and landforms, 27 (4), pp. 391-402.

Panin, A.V., Ivanova, N.N. and Golosov, V.N. 1997. The river network and the processes of erosion and accumulation in the Upper Don basin. Water Resources, 24 (6), pp. 609-617.

Golosov, V.N., Panin, A. 2006. Century-scale stream network dynamics in the Russian plain in response to climate and land use change. Catena, 66 (1,2), pp. 74-92.

Wilkinson, B.H., McElroy, B.J. 2007. The impact of humans on continental erosion and sedimentation. Geological Society of America Bulletin, $119(1,2)$, pp. 140-156.

Pope, I.C., Odhiambo, B.K. 2014. Soil erosion and sediment fluxes analysis: a watershed study of the Ni Reservoir, Spotsylvania County, VA, USA. Environmental monitoring and assessment, 186 (3), pp. 1719-1733.

Мозжерин В.И. Новые результаты стационарного изучения крипа в Среднем Поволжье / В.И. Мозжерин // Экзогенные процессы и эволюция рельефа. - Казань: Изд-во Казан. ун-та, 1985. - С. $124-138$.

Sycheva S.A. 1999. Cycles of soil formation and accumulation in the Holocene// Eurasian soil science. Volume 32, Issue 6, pp. 613-623.

Young A. 1960. Soil movement by denudational processes on slopes // Nature/ Volume 188, Issue 4746.

Dedkov, A.P., Mozzherin, V.I., Tchasovnikova, E.A. Field station study of soil creep in the central Volgaland // Zeitschr. für Geomorphologie, 1978, Suppl. 29.

Rosenbloom, N.A., Doney, S. C., Schimel, D.S. 1998. Hillslope mass transport, catenary sequences, and soil organic matter. Presented at the 1998 Fall Meeting of the American Geophysical Union. San Francisco, CA. December 1998. EOS Abstract. Volume 79, Issue 45, $264 \mathrm{p}$.

Kurbanova S.G., Denmukhametov R.R., Sharifullin A.N. 2014 . Assessment of speed of the recent floodplain alluvium accumulation in basins of minor rivers of the East of the Russian Plain // Life Science Journal. Volume 11. Issue 11, pp. 480-483.

Knox J.C. 2001. Agricultural influence on landscape sensitivity in the Upper Mississippi River Valley/l Geomorphology. Volume 42, Issue 2-4, pp.193-224. 